\title{
sciendo
}

CIVIL AND ENVIRONMENTAL ENGINEERING REPORTS

E-ISSN 2450-8594

CEER 2021; 31 (3): 0265-0275

DOI: 10.2478/ceer-2021-0045

Original Research Article

\section{THE INFLUENCE OF THE POLES' LIFESTYLE ON THE QUANTITY AND QUALITY OF MUNICIPAL WASTEWATER}

\author{
Ewelina PŁUCIENNIK-KOROPCZUK, Martyna MYSZOGRAJ ${ }^{1}$, \\ Sylwia MYSZOGRAJ \\ University of Zielona Góra, Zielona Góra, Poland
}

\begin{abstract}
The article presents lifestyle as an important factor determining the quantity and quality of municipal wastewater. The characteristic of wastewater in Poland has changed significantly in recent years. The qualitative characteristics of municipal wastewater indicate an increase of organic compounds and in the scope of micro-contaminants identified in them, e.g. nanoparticles, microplastics, pharmaceutical and personal care products or heavy metals. Therefore, the knowledge of parameters such as: $\mathrm{BOD}_{5}, \mathrm{COD}$, total $\mathrm{N}$, total $\mathrm{P}$ and suspension solids is no longer sufficient for the design and operation of wastewater treatment systems. Comprehensive research in this area is necessary to select those indicators that better describe the characteristics of wastewater.
\end{abstract}

Keywords: wastewater characteristic, biodegradability, COD fractionation, PPCPs

\section{INTRODUCTION}

Lifestyle is a consequence of matching the possibilities of human existence to changing social and economic conditions. It is an important factor determining the size and structure of consumption of goods. In recent years, Poland has been observing an increase of economic development as well as a change in the style

${ }^{1}$ Corresponding author: University of Zielona Góra, Scientific Circle of Environmental Engineering, student of Biomedical Engineering, e-mail: 102066@stud.uz.zgora.pl 
and standard of living of its inhabitants. Consumer behaviour and broadly understood lifestyle of contemporary Poles are in large part a duplication of attitudes typical of affluent societies, such as changes in the way of eating, food waste, growing trend in the use of catering facilities, the use of more chemicals in households (cosmetics, domestic detergents) and household appliances using new technological solutions.

The characteristics of municipal wastewater is mainly affected by the water supply and sewage infrastructure in a given area and factors resulting from the way of life of residents. In Poland, after 1990, the amount of water consumed per capita decreased. Saving water by households is the result of rising prices and widespread metering of water consumption. As a consequence of reducing the amount of water consumed, the amount of municipal wastewater brought to the treatment plant decreased. In addition, numerous investments in the renovation and modernization of the sewerage network have increased its tightness by eliminating the inflow of infiltration waters and thus the process of wastewater dilution. Whereas the latest publications and reports on the qualitative characteristics of municipal wastewater indicate an increase in the scope of microcontaminants identified in them, e.g. priority substances and so-called emerging contaminants. The presence of chemical compounds practically in all spheres of human life has meant that they are also present in municipal wastewater. The characteristics of contaminants present in wastewater thus changed.

\section{LIFESTYLE AND CONSUMPTION OF GOODS}

Lifestyle is an important factor determining the size and structure of consumption of goods. The standard and lifestyle of the society depends to a large extent on its wealth, which is decisively influenced by the level of education, employment profile and place of residence. In Poland $25.3 \%$ of the population has higher education, $32.1 \%$ - post-secondary and secondary, $21 \%$ - basic vocational, and $21.6 \%$ - lower secondary education, basic education or no education. The difference in the level of education of urban and rural residents remains constant. The share of people with the lowest education or without education was twice as high in rural areas than in cities. In cities, $23.4 \%$ of society has higher education, while in rural areas $-9.3 \%$ [8].

Despite the differences described, the financial situation of households in Poland is clearly improving, the Polish society is getting richer. Over half of Poles assessed their material situation as average. The percentage of households assessing their financial situation as rather good or very good increased to the level of $37.2 \%$ and the percentage of farms perceiving it as rather bad or bad decreased to $11.2 \%$. Farms from rural areas assess their financial situation worse than residents of cities, especially from centres with 500,000 inhabitants and 
above. Among the socio-economic groups, the self-employed rated their material situation best, and the pensioners - worst [9].

There is observed a trend called lazy (comfortable) consumption. It involves the interest in resources that facilitate a comfortable life, which is manifested by the increased demand for products characterized by a high degree of preparation for consumption and the use of semi-finished products. The expenditure on restaurants and hotels is systematically increasing, which in 2017 accounted for $4.6 \%$ of total household expenses [8]. According to data from 2015, every third person ate out during the week and weekend. Among consumers eating out, there is no habit of taking leftovers and such food waste is characteristic of affluent societies. In highly developed countries, $95-115 \mathrm{~kg}$ of discarded food is distributed per consumer per year. The largest food losses result from consumption in households, supermarkets and catering establishments $[21,22,33]$.

\section{WASTEWATER CHARACTERISTIC}

\subsection{Quantity of wastewater}

The residence and living conditions of the population, which are improving, also affect the lifestyle and characteristics of wastewater, as evidenced by a growing percentage of apartments equipped with sanitary installations and equipment. In September 2021, the population in Poland was 37,797,627, of which $60.1 \%$ lived in the urban area, and $39.9 \%$ in the rural area. Almost $91.9 \%$ of the total population used the water supply network, of which over $96.5 \%$ of the total population in urban areas had access to the water supply and $85 \%$ in rural areas. $70.2 \%$ of the total population used the sewage system, of which $90.0 \%$ in urban areas and $40.3 \%$ in rural areas. The amount of total sewage discharged (living, industrial and rainwater) amounted to $1289.8 \mathrm{hm}^{3}$, including households - 938.1 $\mathrm{hm}^{3}(72.7 \%)$. In urban areas it was $818.5 \mathrm{hm}^{3}$, and in rural areas $119.6 \mathrm{hm}^{3}$. In the case of areas insufficiently developed in terms of sewage infrastructure, some residents use home sewage systems: septic tanks and home sewage treatment plants. Liquid waste from septic tanks are collected from owners and delivered to sewage treatment plants or sewage collection stations. Approximately $23.1 \mathrm{hm}^{3}$ of liquid waste was collected, which corresponds to approx. $2.1 \%$ of the total amount of household wastewater discharged via a sewage system to a wastewater treatment plant. From the total amount of liquid waste discharged to wastewater treatment plants or sewage collection stations, approximately $70.0 \%$ came from households [10].

The amount of domestic wastewater produced directly depends on the amount of water consumed by households. Before 1990, there was high water consumption in Poland, as the water fees were flat and depended only on the size of the flat, 
not on actual consumption. Such a fee system did not create incentives to save water or to improve the operation of the water supply system. For a typical flat, the standard was $7.5 \mathrm{~m}^{3} / \mathrm{M}$ monthly (240 litres per person and day). The obligation to install water meters in apartments in new buildings, introduced in 1992 by the Ministry of Construction and Land Management, resulted in a significant decrease in water consumption observed until 2000. This was determined by economic reasons, because there was a direct relationship between the amount of water consumed and the fee paid. The public didn't need to be convinced to the purpose of saving water so much. The data indicate that water consumption in Polish cities is below the established standards of unit water consumption for household and economic purposes [19,25,27]. Since 2004, the average annual water consumption per person has been at the level of $32.2 \mathrm{~m}^{3}[10]$.

The phenomenon of reducing water consumption can be assessed positively, because it involves rational water management. The standard of housing equipment with water and sewage systems has reached a high level. Excellent sanitary technology favours saving water and prevents the effects of waste. Water supply installations are made of better quality materials.

\subsection{Quality of wastewater}

An increase in the load of organic pollutants in wastewater is observed, resulting, among others, from the disposal of catering waste. Increasing costs related to safe and hygienic utilization caused that restaurant owners began to look for other, less burdensome solutions. It has become common to mount colloidal mills under the sink, which "solved" not only the problem of waste collection, but also its collection [5]. Tests carried out in Olsztyn confirmed that none of the 40 catering establishments used rendering services [11]. According to the results of qualitative research on catering waste produced in the canteen at the University of Clarkson in the USA, the average COD of waste introduced by colloidal mills to the sewage system ranged from 500 to $2,000 \mathrm{kgO}_{2} / \mathrm{m}^{3}$ and varied depending on the time of day and day of the week and month [30]. Higher values were for evening meals. Then, the average concentration of COD for each day of the week ranged from 500 to $3,000 \mathrm{kgO}_{2} / \mathrm{m}^{3}$. Single samples had COD of up to 6,000 $\mathrm{kgO}_{2} / \mathrm{m}^{3}$. The values shown are incredibly high compared to the municipal sewage $\mathrm{COD}$, the value of which is usually in the range of 0.500 to 0.700 $\mathrm{kgO}_{2} / \mathrm{m}^{3}$ ). These data show that the load of organic pollutants in $1 \mathrm{~m}^{3}$ of catering waste may correspond to the pollution load contained in $2,000 \mathrm{~m}^{3}$ of municipal wastewater. The seriousness of the problem is also demonstrated by the amounts of pollutants very difficult to biological decomposition, such as fats and oils present in large quantities in catering wastewater. Their concentration can be up to $6.5 \mathrm{~kg} / \mathrm{m}^{3}$ [11]. In the absence of pre-treatment devices, discharge of such contaminated waste into the sewage system has a significant impact on the quality 
of raw sewage flowing into sewage treatment plants. Catering establishments are not the only source of the problems described. Also from individual households, especially in cities, meal remnants, food fats and oils reach the sewage system [27]. Tables 1 and 2 present changes in the basic parameters of raw wastewater and pollutant loads calculated per equivalent inhabitant following the introduction of kitchen waste into the sewage system.

Table 1. Extra organic and nutrient loading of wastewater attributed to Food Waste Disposers [2]

(BOD - Biochemical Oxygen Demand, SS - Suspended Solids)

\begin{tabular}{|c|c|c|c|c|}
\hline \multirow{2}{*}{ Normal domestic wastewater } & \multicolumn{2}{|c|}{ BOD g/capita/day } & \multicolumn{2}{|c|}{ SS g/capita/day } \\
\hline & Range & Typical & Range & Typical \\
\hline $\begin{array}{l}\text { Without contribution from ground } \\
\text { kitchen wastes }\end{array}$ & $59-109$ & 81.7 & $\begin{array}{l}59- \\
113\end{array}$ & 90.7 \\
\hline $\begin{array}{l}\text { With contribution from ground kitchen } \\
\text { wastes }\end{array}$ & $82-118$ & 99.8 & $\begin{array}{l}91- \\
150\end{array}$ & 117.9 \\
\hline$\%$ increase per capita & - & 25 & - & 33 \\
\hline
\end{tabular}

Table 2. Quantity of waste discharged by individuals on dry weight basis [2] (BOD Biochemical Oxygen Demand, COD - Chemical Oxygen Demand, SS - Suspended Solids)

\begin{tabular}{|c|c|c|c|c|}
\hline \multirow{2}{*}{ Parameter } & \multicolumn{4}{|c|}{ g/capita/day } \\
\cline { 2 - 5 } & Range & $\begin{array}{c}\text { Typical without } \\
\text { ground-up kitchen } \\
\text { waste }\end{array}$ & $\begin{array}{c}\text { Typical with } \\
\text { ground-up kitchen } \\
\text { waste }\end{array}$ & $\begin{array}{c}\% \text { increase } \\
\text { of load }\end{array}$ \\
\hline BOD & $50-120$ & 80 & 100 & 25.0 \\
\hline COD & $110-295$ & 190 & 220 & 15.8 \\
\hline TSS & $60-150$ & 90 & 110 & 22.2 \\
\hline Oil and grease & $10-40$ & 30 & 34 & 13.3 \\
\hline
\end{tabular}

In addition to kitchen waste, personal hygiene products, nappies, ear sticks, cotton wads, cigarette butts, coffee grounds, cat litter, condoms, paper towels, expired medicines, used batteries and even garments are also thrown into the sewage system. The composition of screenings retained in the mechanical part of the wastewater treatment plant testifies to what is thrown into the sewage system outside its intended use:

- fraction with grain size $<10 \mathrm{~mm}$ : from 2 to $10 \%$,

- food waste of vegetable origin: from 0.5 to $13 \%$,

- food waste of animal origin: up to $9 \%$,

- paper waste and cardboard: from 6 to $50 \%$, 
- plastics: from 2 to $18 \%$,

- textile materials: from 2 to $26 \%$,

- other organic waste: from 9 to $65 \%$,

- other mineral waste: up to $8 \%[3,6,30]$.

A modern lifestyle means saving time for housework, which involves investing in household appliances. The number of households equipped with durable goods, such as an automatic washing machine and a new generation dishwasher, is increasing, while the level of older equipment is falling. The standard of equipment depends on the region of Poland, the class of the place of residence and the level of education. In 2005, less than $5 \%$ of households were equipped with a dishwasher, and $80 \%$ with an automatic washing machine, while in 2017 this percentage was $31.8 \%$ and $96.3 \%$, respectively [8].

The results of detailed studies on the composition of wastewater discharged from basic household appliances have been published in the report on Sources of critical contaminants in domestic wastewater: contaminant loads from household appliances [4]. Analysis of the composition of wastewater discharged from sanitary fixtures and household appliances, free of man-made pollution (e.g. dishwasher without dirty dishes) showed that in the wastewater from the dishwasher and the washing machine the concentration of pollutants were significantly higher than in other devices. With regard to the parameters of tap water, the $\mathrm{pH}$ value changed from -0.2 to +1.7 units, the intensity of the colour depended on the type of detergents and increased from 100 to $1000 \%$ depending on the device. Wastewater from the dishwasher had the highest colour $(66 \mathrm{Pt} / \mathrm{L})$ and the lowest $(12 \mathrm{Pt} / \mathrm{L})$ was from the shower. Wastewater from the dishwasher was characterized by the highest conductivity (from $5,315 \mu \mathrm{S} / \mathrm{cm}$ to $10,321 \mu \mathrm{S} / \mathrm{cm}$ ) and the largest amount and the highest concentrations of metals (As $145 \mu \mathrm{g} / \mathrm{L}, \mathrm{Al}$ $0.27 \mathrm{mg} / \mathrm{L}, \mathrm{Cu} 0.434 \mathrm{mg} / \mathrm{L}, \mathrm{Sr} 0.071 \mathrm{mg} / \mathrm{L}, \mathrm{V} 0.026 \mathrm{mg} / \mathrm{L}, \mathrm{Ba} 0.0226 \mathrm{mg} / \mathrm{L}$ ) were identified in them, which is the result of the small volume of discharged sewage and the sample concentration. On the other hand, wastewater from the washing machine was the largest source of dissolved substances on average $82.2 \mathrm{~g} / \mathrm{wash}$ $[4,29]$.

\subsection{Emerging contaminants}

The growing problem is the presence of nanoparticles, microplastics (plastic particles with a diameter less than $1 \mathrm{~mm}$ ) and pharmaceutical substances in wastewater.

In the last twenty years, the cosmetics industry has been strongly influenced by detergents. Both the detergents and cosmetics use generally available ingredients such as surfactants, natural extracts and others. They move away from simple, formerly used compositions towards more complex recipes. Popular detergents in 
the form of powders, liquids and capsules increase the concentration of pollutants in wastewater. In addition to the increase in turbidity, colour intensity, phosphorus concentrations, there was also more than 3 -fold increase in COD values, and $\mathrm{BOD}_{5}$ kinetics indicate the presence of non-degradable compounds in detergents [16]. During the use and operation of products containing nanomaterials, nanocomponents and nanoparticles may be released, e.g. in the washing process of socks with nanosilver, silver ions and silver in a colloidal form are released into the water. In addition, it was shown that in the drainage water from a washing machine enriched with nanomaterials, the content of released nanosilver was 11 $\mu \mathrm{g} / \mathrm{dm}^{3}[1]$. The presence of nanoparticles in wastewater and sewage sludge has been confirmed in many studies. Due to the high antibacterial potential, a wide range of biocidal activity and the ability to penetrate bacterial cells, silver nanoparticles can reduce the biodiversity of microorganisms and threaten the species used in the biodegradation of pollutants, including microorganisms used in sewage treatment $[12,15,18,32]$. Microplastic is a component of plastics, synthetic clothing and cosmetics (e.g. hair shampoo). As a result of using cosmetics and washing clothes in automatic washing machines, the microplastic particles are washed out.

The current research carried out all over the world show a common occurrence of xenobiotics in the aquatic environment, among which a special group are PPCPs (Pharmaceutical and Personal Care Products), including pharmaceuticals and personal care products. Pollutants from the PPCPs group are a serious problem, because they already pose a threat to the proper functioning of aquatic organisms in small quantities. Therefore, PPCPs are currently the subject of intensive research. Pharmaceutical manufacturers find many recipients of their products. Important partners of pharmaceutical concerns interested in buying this type of substance are pharmacies, hospitals, health centres, as well as a growing group of individual consumers using a wide range of over-the-counter medicines [14,24]. In 2016, 75.9\% of people used at least one of the medicines or dietary supplements. Medicines were more often used by women $(82.3 \%)$ than men $(69.2 \%)$. The consumption of drugs or dietary supplements was influenced by factors such as health status, age, long-term health problems, chronic diseases lasting longer than half a year or disability of the respondent. Medicines/supplements were used by $54.4 \%$ of people with a very good assessment of health, $73.0 \%$ with good, $93.3 \%$ with neutral and almost all assessing their health condition negatively (98.7\%). Most medicines users were registered among people with long-term health problems $(95.7 \%)$ and with chronic diseases $(97.5 \%)$. This percentage was high among respondents with a degree of disability (significant $-94.9 \%$, moderate $-98.5 \%$, light $-95.1 \%$ ) and for children with a disability certificate $(88.5 \%)$. The most often, medicines were 
taken by elderly people, aged 60 or more $-91.0 \%$ of sixty-year-olds, $96.8 \%$ of seventy-year-olds and $98.2 \%$ of respondents aged 80 and more. The share of people consuming medicines or dietary supplements among the lowest-income groups was $73.8 \%$ and increased with the improvement of the material situation. Inequalities due to the amount of income may cause difficulties in the purchase of medicines by some groups of people. Higher medicine consumption, which occurs among people with the highest income, as well as among residents of large cities $(80.5 \%)$, may result from the use of medicines from the group "other" or dietary supplements. Analysing the types of medicines used, it can be seen that $36.8 \%$ of people used medications for headaches, more often women $(43.1 \%)$ than men $(28.9 \%)$. Next, medicines were used for cardiovascular diseases (28.1\%) and antibiotics (27.1\%). $47.7 \%$ of people took dietary supplements. Among children, antibiotics and medications for allergy symptoms were the most commonly used medicines. On the other hand, people aged 80 and more are more likely than people in other age groups to take medicines for cardiovascular diseases, arthralgia and diabetes. Taking into account the place of residence, allergy medicines were used more by urban residents (10.1\%) than in rural areas (7.2\%) [7]. By consuming pharmaceuticals, we do not think that the remnants of the drug and its metabolites, along with other waste products, are excreted from the body. And then they will get to the wastewater. Unused and expired pharmaceuticals are often thrown directly into the sewage system, not into containers in pharmacies. In the group of respondents constantly taking medicines and people using them ad hoc, 33.1 and $24.2 \%$ respectively, confirmed that unnecessary medicines are thrown into the toilet [17]. It is also one of the causes of the occurrence of drugs in sewage, which changes its composition and potential biodegradability in biological treatment processes. The first studies on the presence of contaminants of pharmaceutical origin were detected in the aquatic environment in the USA in the 1970s. At the end of the 20th century, rivers in Germany were also monitored, as well as purified wastewater and surface water and drinking water. Analgesics and anti-inflammatory, psychotropic, antiepileptic medicines, beta-blockers, fat regulators and their metabolites, including antibiotics and hormones were found in it. At the turn of the century, as a result of extensive research, it was also established that in surface waters there are most often OTC medicines, antibiotics and hormones [13,14,20,26,31]. Sex hormones include natural estrogens: estrone, $17 \beta$-estradiol, estriol, and synthetic estrogens, including etinyloestradiol. They are used in hormone replacement therapy and as a component of contraceptives. The load of estrogen in municipal wastewater depends on the population of people living in the area. It depends on the number of women in childbearing age, pregnant women, menopausal women (the body of a pregnant woman produces 120 times more $17 \beta$-estradiol compared to a nonpregnant woman), on the number of women taking hormone-containing 
medicines. The highest concentration of estrogens in treated wastewater was detected in wastewater treatment plants using the simplest treatment methods [28].

\section{CONCLUSION}

Until recently, the knowledge of such parameters as: $\mathrm{BOD}_{5}, \mathrm{COD}$, total $\mathrm{N}$, total $\mathrm{P}$ and suspended solid [23], was enough to design and operate wastewater treatment systems. Considering the described aspects, it seems important to adjust the wastewater quality indicators adopted, for example, for design purposes. Detailed determination of new contaminants and substances identified as priorities is time-and cost-intensive. Comprehensive research in this field is necessary to select those indicators that will better describe the characteristics of wastewater. As of today, the adoption of COD as the main parameter determining the amount of organic carbon in wastewater and the division of COD into fractions describing various degrees of biodegradability is a milestone in a new approach to modeling biological wastewater treatment processes [20].

\section{REFERENCES}

1. Benn, TM and Westerhoff, P 2008. Nanoparticle silver released into water from commercially available sock fabrics. Environ. Sci. Technol. 42, 41334139.

2. Carey, C, Phelan, W and Boland, C 2008. Examining the use of food waste disposers (2005-WRM-DS-23-M1) Programme 2007-2013 STRIVE Report Series No.11, Environmental Protection Agency.

3. Clay, S, Hodgkinson, A, Upton, J and Green, M 1996. Developing acceptable sewage screening practices, Water Science and Technology, 33(12), 229-234.

4. Diaper, C et.al 2008. Sources of critical contaminants in domestic wastewater: contaminant loads from household appliances. Water for a Healthy Country Flagship Report series ISSN: 1835-095X.

5. Dzwolak, W 2010. Where to throw away, so as not to hurt? Dangerous kitchen waste and food waste. Gastronomic Review, 64 (10), 3 (in polish).

6. Fudala - Książek, S and Boguski, A 2008. Evaluation of the quality of screenings and mineral slurry from wastewater treatment in the aspect of their disposal. Gas, Water and Sanitary Technology 5, 26-32, (in polish).

7. Health care in households in 2016. Statistics Poland Warsaw 2018 ISBN 97883-7027-688-1(in polish).

8. Household budget survey in 2017. Statistic Poland, Warsaw 2018 ISSN 02089793. 
9. Incomes and living conditions of the population of Poland (report from the EU-SILC survey of 2016), Statistic Poland Warsaw 2017 ISSN 1898-9322.

10. Municipal infrastructure w 2016r. Statistics Poland Warsaw 2017 (in polish).

11. Janukowicz, W, Rodziewicz, J, Mielcarek, A and Wolter, A 2016. The impact of food waste disposal to the municipal sewage network on the COD concentration of municipal sewage in Olsztyn. Ecological Engineering 47, pp. 68-73 DOI: 10.12912/23920629/62849 (in polish).

12. Kampe, S, Kaegi, R, Schlich, K, Wasmuth, C, Hollert, H and Schlechtriem, C 2018. Silver nanoparticles in sewage sludge: Bioavailability of sulfidized silver to the terrestrial isopod Porcellio scaber. Environ Toxicol Chem.37(6):1606-1613. doi: 10.1002/etc.4102.

13. Kasprzyk-Hordern, B, Dinsdale, RM and Guwy, AJ 2008. The occurrence of pharmaceuticals, personal care products, endocrine neutral pharmaceuticals disruptors and illicit drugs in surface water in South Wales, UK. Water Research, 42, 3498-3518.

14. Koszowska, A, Ebisz, M and Krzyśko-Łupicka, T 2015. Pharmaceuticals and personal care products in the aquatic environment as a new issue of environmental health. Environmental Medicine, 18,1,62-69.

15. Hou, L, et al. 2011. Removal of silver nanoparticles in simulated wastewater treatment processes and its impact on $\mathrm{COD}$ and $\mathrm{NH}_{4}$ reduction. Chemosphere 87,3, 248-252.

16. Malarski, M, Matusiak, K and Cybula, J 2016, The influence of selected household chemical products on the quality of greywater. Scientific Review Engineering and Environmental Sciences,71,61-71 (in polish).

17. Matuszczak, M 2015. Sewerage is not a garbage dump. Water works and sewerage, 3(133) (in polish).

18. Meier, $\mathrm{C}$ et al. 2016. Transformation of Silver Nanoparticles in Sewage Sludge during Incineration. Environ Sci Technol.5;50(7):3503-10. doi: 10.1021/acs.est.5b04804.

19. Pasela, R and Gorączko, M 2013. Analysis of selected factors shaping water consumption in multi-family buildings, Annual Set The Environment Protection, 15, ISSN 1506-218X 1658-1672 (in polish).

20. Płuciennik-Koropczuk, E and Myszograj, S 2020. Changes in quantity of nonbiodegradable organic micropollutants in municipal wastewater based on COD fractionation. Desalination and Water Treatment, 186, 334-340, ISSN: 1944-3994, eISSN: 1944-3986.

21. Poland on the plate 2015, Report prepared on the basis of the study IQS https:/www.grupaiqs.pl/wpcontent/uploads/2015/04/raport_polska_na_taler zu_2015.pdf (in polish).

22. Poland on a plate 2017, Polish HoReCa market. Marko Cash \& Cary Poland report prepared by IQS (in polish). 
23. Guide for the operator of the sewage treatment plant, ed. Dymaczewski Z., Poznań 2011. ISBN 978-83-89696-38-X (in polish).

24. Rezka, P and Balcerzak, W 2015. The occurrence of non-steroidal antiinflammatory drugs in wastewater and water environment and methods of their removal - selected issues, Archives of Waste Management and Environmental Protection ISSN 1733-4381, 17,1,33-38 (in polish).

25. Regulation of the Minister of Infrastructure of January 14, 2002 on the determination of average water consumption standards. (Dz. U. $2002 \mathrm{nr} 8$ poz. 70) (in polish).

26. Schmidt, W and Clare, HR 2015. Evaluation of biological end points in crop plants after exposure to non-steroidal anti-inflammatory drugs(NSAIDs): Implications for phyto toxicological assessment of novel contaminants. Ecotoxicology and Environmental Safety 112,212-222.

27. Staniszewska, A et al. 2015. Selected aspects related to expired medications, Probl. Hig. Epidemiol., 96(3):697-703 (in polish).

28. Szelągm, Z and Malczewska, B 2016. Assessment of changes in water abstraction in selected cities of the Lower Silesian Voivodship in the years 2005-2010. Ecological Engineering, 50,106-114.

29. Szymonik, A and Lach, J 2013. Pharmaceuticals in surface and drinking water. Proceedings of ECOpole, 7(2), DOI: 10.2429/proc.2013.7(2)096 (in polish).

30. Tjandraatmadja, G, Pollard, C, Sheedy, C and Gozukara, Y 2010. Sources of contaminants in domestic wastewater: nutrients and additional elements from household products. Water for a Healthy Country Flagship Report series ISSN: 1835-095X.

31. Waldron, A, Gibson, S, Pohl, L and Labas, K 2012. Anaerobic digestion of cafeteria waste reducing Clarkson's environmental footprint. Project report. New York State Pollution Prevention Institute.

32. Wasik-Koty, A, Dębska, J and Namieśnik, J 2003. Residues of pharmaceuticals in the environment of transformation, concentration, determination. Soc Ecological Chemistry \& Engineering,10, 723-750 (in polish).

33. Wolska, KI, Markowska, K, Wypij, M, Golińska, P and Dahm, H 2017. Silver nanoparticles, synthesis and biological activity. Kosmos Ser A, 66, 1,(314), 125-138 (in polish).

Editor received the manuscript: 06.07.2021 